\title{
PENGEMBANGAN MODUL PEMBELAJARAN MULTIMEDIA UNTUK MENINGKATKAN MINAT DAN PEMAHAMAN KONSEP MAHASISWA PRODI PENDIDIKAN INFORMATIKA
}

\author{
Yosi Nur Kholisho ${ }^{1}$ \\ ${ }^{1}$ Program Studi Pendidikan Informatika, \\ Fakultas Keguruan dan Ilmu Pendidikan, Universitas Hamzanwadi \\ e-mail: yosink.peinfo@gmail.com ${ }^{1}$
}

\begin{abstract}
Abstrak
Tujuan dalam penelitian ini adalah: (1) mengembangkan dan menghasilkan produk dalam bentuk modul pembelajaran pada mata kuliah multimedia, (2) mengetahui keefektifan modul yang dikembangkan berdasarkan respon minat mahasiswa terhadap hasil belajar. Metode yang digunakan dalam penelitian ini adalah metode penelitian dan pengembangan (Research and Development). Berdasarkan data hasil validasi ahli media dan produk, hasil yang didapatkan bahwa produk berupa modul pembelajaran multimedia untuk mahasiswa dapat dikategorikan"baik" $(37,38<X \leq 46,14)$ dengan jumlah skor 45 dan dari segi tampilan dapat dikategorikan "baik" $(51<\mathrm{x} \leq 63)$ dengan jumlah skor 56. Hasil analisis minat mahasiswa terhadap modul pembelajaran didapatkan hasil bahwa 35 orang dari 45 menyatakan bahwa lebih berminat belajar dengan menggunakan modul dengan persentase sebesar $77,8 \%$, hal ini membuktikan bahwa minat mahasiswa dalam mempelajari materi dengan menggunakan modul baik. Hasil yang diperoleh untuk hasil belajar didapatkan hasil bahwa nilai sebelum diberikan modul 78.7 dan nilai sesudah diberikan modul 87.6 hasil ini menunjukkan bahwa nilai hasil belajar setelah diberikan modul lebih tinggi dibandingkan dengan dengan sebelum diberikan modul.
\end{abstract}

Kata Kunci: Modul Pembelajaran, Minat, Hasil Belajar

\begin{abstract}
The purpose of this research is to develop and produce product in the form of multimedia instructional subjects for students on informatics education course and to know the effectiveness of modules developed based on responses of student interest to learning and learning outcomes. The method used in this research is Research and Development. Based on data from media and product expert validation, it can be seen that the product in the form of multimedia learning module for students can be categorized as "good" $(37.38<X \leq 46.14)$ with total score 45 and in terms of display can be categorized "good" $(51<x \leq 63)$ with a total score of 56. Result of student interest analysis to learning module got result that 35 person from 45 stated that more interest to learn by using module with percentage equal to $77,8 \%$, this proves that student interest in studying material by using good module. The results obtained for the learning outcomes, the results obtained that the value before the given module 78.7 and the value after the given module 87.6 this result shows that the value of learning results after the module is given higher than with the before given the module.
\end{abstract}

\section{PENDAHULUAN}

Undang-Undang Republik Indonesia No. 20 tahun 2003 tentang Sistem Pendidikan Nasional adalah mengembangkan kemampuan dan membentuk watak serta peradaban bangsa yang bermartabat dalam rangka mencerdaskan kehidupan bangsa, bertujuan untuk mengembangkan potensi peserta didik. Peraturan Presiden RI Nomor 8 Tahun 2012 mengeluarkan Kerangka Kualifikasi Nasional Indonesia (KKNI), Kerangka Kualifikasi Nasional Indonesia (KKNI) adalah kerangka penjenjangan kualifikasi kompetensi yang dapat menyandingkan, menyetarakan, dan mengintegrasikan antara bidang pendidikan dan bidang 
pelatihan kerja serta pengalaman kerja dalam rangka pemberian pengakuan kompetensi kerja sesuai dengan struktur pekerjaan di berbagai sektor (Perpres nomor 8 tahun 2012). Bertolak dari penjabaran undang-undang tentang sistem pendidikan nasional dan praturan presiden dentang kerangka kualifikasi nasional indonesia kedua hal tersebut menekankan pada kewajiban mencerdaskan kehidupan bangsa, salah satu cara mencerdaskan kehidupan bangsa dalam bidang pendidikan dan pada jenjang perguruan tinggi pada KKNI menekankan pada mampu mengintegrasikan antara bidang pendidikan dan bidang pelatihan kerja.

Pendidikan memiliki peran penting dalam kehidupan bangsa. Salah satu permasalahan yang dihadapi dalam dunia pendidikan kita saat ini adalah masalah lemahnya proses pembelajaran. Tetapi pada kenyataan sekarang ini mutu pendidikan belum menunjukkan suatu peningkatan hal tersebut disebabkan karena dalam proses pembelajaran anak kurang didorong untuk berfikir secara kreatif.

Belajar merupakan proses yang terjadi pada semua manusia dan berlangsung seumur hidup. Seseorang dikatakan berhasil dalam belajarnya jika adanya perubahan tingkah laku pada diri seseorang tersebut. Berubahan yang dimaksud meliputi, pengetahuan(kognitif), sikap (afektif), dan ketrampilan (psikomotor) (Achdiat,1997:12).

Program studi pendidikan informatika merupakan salah satu program studi yang terdapat di Universitas Hamzanwadi, pada program studi tersebut persentase mata kuliah menekankan akan keterampilan (psikomotor). Salah satu mata kuliah tersebut adalah multimedia interaktif. Dari hasil pengajaran yang telah dilakukan oleh peneliti sebelumnya diperoleh hasil belajar mahasiswa yang kurang baik dan tingkat minat belajar siswa yang kurang baik pula. Dari permasalahan tersebut peneliti mengambil kesimpulan awal bahwa cara penyampaian materi menggunakan metode ceramah kurang memberikan semangat belajar bagi mahasiswa.

Berdasarkan permasalahan tersebut peneliti mencoba mengembangkan bahan ajar berbentuk modul pembelajaran mata kuliah multimedia. Modul yang dikembangkan berisi teori dasar yang dibutuhkan berupa perkenalan sup materi dan juga langkah-langkah dalam membuat multimedia interaktif berupa media-media pembelajaran yang dapat dikembangkan mahasiswa sebagai calon pendidik berbasis Adobe Flash, sehingga diharapkan mahasiswa lebih tertarik dan tertantang disebabkan output atau tampilan akhir ditampilakan dan mahasiswa gambaran untuk memodifikasi projek sesuai kreatifitas mereka.

Tujuan dalam penelitian ini adalah mengembangkan dan menghasilkan produk dalam bentuk bahan ajar modul pembelajaran mata kuliah multimedia bagi mahasiswa program studi pendidikan informatika dan mengetahui keefektifan modul yang dikembangkan berdasarkan respon minat mahasiswa terhadap pelajaran dan hasil belajar.

Manfaat yang dapat diperoleh dari penelitian ini adalah modul multimedia sebagai sumber belajar mandiri siswa baik di kelas maupun di rumah sehingga padat meningkatkan pemanhaman kosep dan minat belajar mahasiswa terhadap mata kuliah multimedia yang berujung pada peningkatan hasil belajar. 


\section{TINJAUAN PUSTAKA}

\section{Multimedia Interaktif}

Multimedia merupakan "multiple media" or "a combination of media. The media can be still graphics and photographs, sound, motion video, animation, and/or text items combined in a product whose purpose is to communicate information in multiple ways (Roblyer \& Doering 2010: 170). Definisi senada dinyatakan Tay dalam Pramono (2007:8) bahwa "Multimedia adalah kombinasi teks, grafik, suara, animasi dan video. Bila pengguna mendapatkan keleluasaan dalam mengontrol maka disebut multimedia interaktif'. Sedangkan menurut Riyana (2007:5), "multimedia Interaktif merupakan alat atau sarana pembelajaran yang berisi materi, metode, batasan-batasan, dan cara mengevaluasi yang dirancang secara sistematis dan menarik untuk mencapai kompetensi/subkompetensi mata pelajaran yang diharapkan sesuai dengan tingkat kompleksitasnya." Dapat disimpulkan bahwa multimedia merupakan sesuatu yang dilengkapi dengan alat pengontrol yang dapat dioperasikan oleh pengguna berupa kombinasi teks, grafik, suara, animasi dan video.

\section{Bahan Ajar}

Seorang pendidik harus mampu mengembangkan bahan ajar yang sesuai dengan aturan pengembangan bahan ajar. Menurut Chomsin S.W. dan Jasmadi (2008: 42) ramburambu yang harus dipatuhi dalam pengembangan bahan ajar adalah : a. bahan ajar harus disesuaikan dengan peserta didik yang sedang mengikuti proses pembelajaran; b. bahan ajar diharapkan mampu mengubah tingkah laku peserta didik; c. bahan ajar dikembangkan harus sesuai dengan kebutuhan dan karakteristik diri; d. program belajar-mengajar yang akan dilangsungkan; e. di dalam bahan ajar telah mencakup tujuan kagiatan pembelajaran yang spesifik; f. guna mendukung ketercapaian tujuan, bahan ajar harus memuat materi pembelajaran secara rinci, baik untuk kegiatan dan latihan; g. terdapat evaluasi sebagai umpan balik dan alat untuk mengukur tingkat keberhasilan peserta didik. Proses pengembangan bahan ajar harus disusun secara sistematis sehingga bahan ajar tersebut dapat menambah pengetahuan dan kompetensi bagi peserta didik secara baik dan efektif.

\section{Modul Pembelajaran}

Modul merupakan bahan ajar yang disusun secara sistematis dengan bahasa yang mudah dipahami oleh siswa, sesuai usia dan tingkat pengetahuan mereka agar mereka dapat belajar secara mandiri dengan bimbingan minimal dari pendidik (Andi Prastowo, 2012: 106). Menurut Rudi Susilana dan Cepi Riyana (2008: 14) modul merupakan suatu paket program yang disusun dan didesain sedemikian rupa untuk kepentingan belajar siswa. Pendekatan dalam pembelajaran modul menggunakan pengalaman siswa. Dari penjelasan tersebut dapat disimpulkan bahwa modul merupakan paket program yang disusun dan didesain sebagai bahan ajar mandiri untuk membantu siswa menguasai pelajaran dan siswa dapat belajar sesuai dengan kecepatannya masing-masing.

\section{Minat Belajar}

Minat merupakan kecenderungan yang menetap dalam subjek untuk merasa tertarik pada bidang atau hal tertentu dan merasa senang berkecimpung dalam bidang itu (Winkel, 1984: 30). Adanya suatu ketertarikan yang sifatnya tetap di dalam diri subjek atau seseorang yang sedang mengalaminya atas suatu bidang atau hal tertentu dan adanya rasa senang 
terhadap bidang atau hal tersebut, sehingga seseorang mendalaminya. Minat adalah kesadaran seseorang, bahwa suatu objek, seseorang, suatu soal atau suatu situasi mengandung sangkutpaut dengan dirinya (Witherington, 1983: 135), merupakan suatu kesadaran yang ada pada diri seseorang tentang hubungan dirinya dengan segala sesuatu yang ada di luar dirinya. Indikator minat ada empat, yaitu: a. perasaan senang; b. ketertarikan siswa; c. perhatian siswa; dan d. keterlibatan siswa (Safari, 2003). Dari penjelasan tersebut dapat disimpulkan bahwa minat belajar adalah adanya perasaan senang, ketertarikan siswa, perhatian siswa dan keterlibatan siswa terhadap pelajaran dan proses pembelajaran.

\section{Pemahaman Konsep dan Hasil Belajar}

Pemahaman adalah kemampuan untuk menjelaskan suatu situasi atau suatu tindakan. Sedangkan konsep adalah suatu kelas atau kategori stimuli yang memiliki ciri-ciri umum. Dapat disimpulkan bahwa pemahaman konsep merupakan kemampuan untuk menjelaskan dan mengartikan suatu konsep atau kategori stimuli yang memiliki ciri-ciri umum.

Hasil belajar dapat diartikan sebagai hasil maksimum yang telah dicapai oleh siswa setelah mengalami proses belajar mengajar dalam mempelajari materi pelajaran tertentu. Hasil belajar tidak mutlak berupa nilai saja, akan tetapi dapat berupa perubahan atau peningkatan sikap, kebiasaan, pengetahuan, keuletan, ketabahan, penalaran, kedisiplinan, keterampilan dan lain sebagainya yang menuju pada perubahan positif. Hasil belajar menunjukkan kemampuan siswa yang sebenarnya yang telah mengalami proses pengalihan ilmu pengetahuan dari seseorang yang dapat dikatakan dewasa atau memiliki pengetahuan kurang.

\section{METODE PENELITIAN}

Rancangan penelitian yang digunakan adalah Metode Penelitian Pengembangan. Metode penelitian pengembangan (Research and Development) adalah metode penelitian yang digunakan untuk menghasilkan produk tertentu, dan menguji kefektifan produk tersebut. Langkah-langkah dalam pengembangan penelitian ini adalah sebagai berikut: 1. potensi dan masalah; 2. pengumpulan data; 3. desain produk; 4. validasi desain; 5; revisi desain; 6. ujicoba produk; 7. revisi produk; 8. ujicoba pemakaian; 9. revisi produk; 10. produksi masal. Pada tahap selanjutnya dilakukan penyebaran angket minat sebagai tanggapan minat siswa terhadap modul pembelajaran multimedia dan tahap akhir untuk melihat pemahaman konsep mahasiswa dilihat dari hasil belajar dipergunakan hasil tes pemahaman konsep.

\section{HASIL DAN PEMBAHASAN}

\section{Deskripsi Data Hasil Validasi Tim Ahli}

Validasi ini dimaksudkan untuk mengetahui tingkat kelayakan produk yang dikembagkan baik dari aspek materi dan desain. Hasil atau penilaian validasi dari ahli materi dan dan ahli desain yang selanjutnya digunakan sebagai dasar untuk mengadakan perbaikan atau revisi agar dapat memperoleh produk yang lebih baik lagi.

Validator ahli materi dan ahli desain dipilih untuk memvalidasi produk pengembangan modul pembelajaran multimedia karena dianggap kompeten dalam bidang tersebut. Data hasil validasi tim ahli materi dan desain yang diperoleh sebagai berikut: 


\section{Data Hasil Validasi Ahli Materi}

Data hasil validasi ahli materi diperoleh dengan cara memberikan produk dalam bentuk modul pembelajaran multimedia dan instrument validasi untuk ahli materi. Berdasarkan hasil validasi yang telah dilakukan maka dapat diketahui bahwa produk berupa modul pembelajaran multimedia dari segi materi/isi dapat dikategorikan "Baik" $37,38<\mathrm{x} \leq 46,14$ dengan jumlah skor 45.

\section{Data Hasil Validasi Ahli Desain}

Data hasil validasi ahli desain diperoleh dengan cara memberikan produk berupa modul pembelajaran multimedia dan instrument validasi untuk ahli desain. Berdasarkan hasil validasi yang telah dilakukan maka dapat diketahui bahwa produk berupa modul pembelajaran multimedia dari segi desain dapat dikategorikan "Baik" $(51<\mathrm{x} \leq 63)$ dengan jumlah skor 56.

Dari hasil validasi produk dan desain diproleh hasil baik sehingga produk berupa modul pembelajaran multimedia dapat diterapkan sebagai bahan ajar pada proses pembelajaran mata kuliah multimedia.

\section{Analisis Data}

\section{Pemahaman Konsep (Hasil Belajar)}

Data hasil analisis belajar mahasiswa selama pemberian modul yaitu dengan diberikan tes ujian pada akhir pertemuan untuk mengukur pemahaman konsep multimedia mahasiswa. Berdasarkan nilai rata-rata hasil belajar sesudah diberikan modul dan sebelum diberikan modul yaitu 87.6 dan 78.7 dapat diketahui bahwa nilai hasil belajar mahasiswa setelah diberikan modul lebih tinggi dibandingkan dengan dengan sebelum diberikan modul. Hal ini di karenakan modul belajar bagi mahasiswa memberikan kesempatan pada mahasiswa untuk mengembangkan kemampuan disebabkan tampilan pada modul telah dijabarkan output atau hasil akhir dari projek tersebut dan mahasiswa memiliki gambaran untuk mengembangkan atau memodifikasi projek.

\section{Minat Belajar}

Dari hasil analisis sebelum dan sesudah diberikan modul didapatkan bahwa terdapat perbedaan minat belajar antara sebelum dan sesudah diberikan modul pembelajaran, hal dibuktikan dengan dari hasil angket responden yang disebarkan kepada 45 orang mahasiswa didapatkan hasil bahwa 35 orang menyatakan bahwa lebih berminat belajar dengan menggunakan modul dengan persentase sebesar $77,8 \%$ dan sisanya menyatakan sama saja.

\section{Pembahasan}

Pengembangan modul pembelajaran multimedia bagi mahasiswa prodi pendidikan informatika diperoleh hasil baik dari ahli media dan ahli desain, sehingga produk berupa bahan ajar modul multimedia dapat dipergunakan sebagai bahan ajar bagi mahasiswa pada mata kuliah multimedia interaktif.

Berdasarkan hasil penelitian yang telah dilaksanakan didapatkan hasil bahwa adanya peningkatan minat belajar mahasiswapada materi multimedia program studi pendidikan informatika khususnya pada pokok materi praktikum. Peningkatan minat belajar dapat terlihat secara kualitatif dan kuantitatif. Peningkatan tersebut terlihat pada saat mahasiswa antusias dan bersemangat dalam mengerjakan projek menggunakan modul pembelajaran 
multimedia, terlihat pula dari angket yang diberikan 77,8\% menyatakan lebih berminat belajar dengan menggunakan modul pembelajaran. Dari penjabaran tersebut minat mahasiswa dapat meningkat dikarenakan terdapat kepercayaan yang diberikan kepada mahasiswa untuk dapat menyelesaikan dan dapat mengembangkan projek sesuai dengan kreatifitas mahasiswa, keberhasilan dan kecepatan dalam menyelesaikan modul yang diberikan tergantung dengan semangat belajar masing-masing individu.

Berdasarkan hasil belajar mahasiswa untuk melihat pemahaman konsep mata kuliah multimedia, diperoleh adanya peningkatan hasil belajar mahasiswa sebelum dan setelah diberikan modul pembelajaran. Hasil yang diberoleh tidak begitu signifikan akan tetapi ada perubahan yang baik dalam hasil belajar. Hal tersebut dikarenakan muncul motifasi dan minat belajar pada diri mahasiswa sehingga kreatifitas mahasiswa pada pembuatan projek meningkat dan pada akhirnya menghasilkan hasil belajar yang baik pada mahasiswa prodi pendidikan informatika.

\section{SIMPULAN}

Berdasarkan hasil dan pembahasan yang telah dijabarkan di atas, dapat disimpulkan bahwa modul pembelajaran yang dikembangkan ternyata layak untuk digunakan sebagai bahan ajar bagi mahasiswa prodi pendidikan informatika. Selain itu juga, dengan diterapkannya modul pembelajaran ini dapat meningkatkan minat dan hasil belajar mahasiswa.

\section{REFERENSI}

Achdiat K, Mihardja. (1997). Polemik Kebudayaan:Pokok Pikiran St. Takdir Alisjahbana. Yogyakarta: Pustaka Jaya.

Andi, Prastowo. (2012). Panduan Kreatif Membuat Bahan Ajar Inovatif. Yogyakarta: Diva Press.

Chomsin S. Widodo dan Jasmadi. (2008). Panduan Menyusun Bahan Ajar Berbasis Kompetensi. Jakarta: PT Elek Media Komputindo.

Depdiknas. (2003). Undang-undang RI No.20 tahun 2003. Tentang Sistem Pendidikan Nasional.

Pramono, Gatot. (2007). Aplikasi Component Display Theory dalam Multimediadan Web Pembelajaran. Departemen Pendidikan Nasional PusatTeknologi Informasi dan Komunikasi Pendidikan.

Presiden RI. (2012). Peraturan Presiden RI Nomor 8 Tahun 2012. Tentang Kerangka Kualifikasi Nasional Indonesia (KKNI).

Riyana, Cheppy. (2007). Pedoman Pengembangan Media Video. Jakarta: P3AI UPI.

Roblyer, M.D. and Doering, A.H. (2010). Integrating Educational Technology into Teaching. Boston: Pearson Education, Inc. 
e-ISSN 2549-7472

Volume 1, Nomor 1, Juni 2017

Susilana, Rudi dan Riyana, Cepi. (2008). Media Pembelajaran. Bandung: CV Wacana Prima.

Safari. (2003). Evaluasi Pembelajaran. Departemen Pendidikan Nasional Direktorat Jendral Pendidikan Dasar dan Menengah Direktorat Tenaga kependidikan.

Winkel. (1984). Psikologi Pendidikan dan Evaluasi Belajar. Jakarta: Gramedia.

Witherington. (1983). Psikologi Pendidikan. Jakarta: Aksara Baru 